\title{
From Windsor Castle to White City: The 1908 Olympic Marathon Route
}

\author{
MARTIN POLLEY \\ University of Southampton, UK
}

In 1908, London hosted the fourth Olympic Games. A centrepiece of the Olympics, still in a nascent form after their creation in 1896, was the marathon, a foot-race of approximately $40 \mathrm{~km}$. The race was run from Windsor Castle to the Olympic Stadium at Shepherd's Bush in July 1908, and quickly became famous for its controversies, such as the judges' assistance that helped Dorando Pietri over the line, and the questionable amateur status of Canadian runner Tom Longboat. This paper will concentrate on the route of the race: on how it was planned by the Polytechnic Harriers, how it was managed on the day, how it contributed to the development of 'marathon fever' after the Olympics, and what it tells us about the growing suburban landscape of Edwardian London and its hinterlands. The paper will end with a survey of the route today.

In 20I2, London will become the first city to host the Olympic Games for a third time. The Olympic Park in east London's Lower Lea Valley will follow on from the White City in 1908 and Wembley in 1948 as the focal point of the capital's games. Many of the events, including athletics, swimming, and track cycling, will take place in purpose-built venues on this site, but others will be held away from the centre. Three sports will go to existing London venues, with Wimbledon taking the lawn tennis, Wembley having some of the football, and Lord's hosting the archery. Other events will happen away from London, as part of the organisers' plan to promote more than just the English capital city: the sailing at Weymouth, the rowing and canoeing at Eton, and the football matches in Birmingham, Cardiff, Glasgow, Manchester, and Newcastle, are part of this trend. Still more events will be placed in historic sites around London, including the equestrian events in Greenwich Park, the open water swimming in the Serpentine, and the beach volleyball on Horse Guards Parade. ${ }^{\mathrm{I}}$

One of the most popular events in any Olympic Games, and one that has to move beyond the constraints of the stadium and onto the host city's streets, is the marathon. In 20I2, this 26-mile 385-yard race will make the most of London's tourist sites. Starting on the southern end of Tower Bridge, the runners will cross the Thames, run 
three laps of a circuit that takes in the Tower of London, the Houses of Parliament, Westminster Abbey, Buckingham Palace, Trafalgar Square, and St Paul's Cathedral, and then head east to finish at the stadium. The route's planners clearly aim to provide a city-wide spectacle that will appeal to both live and television audiences, and that will serve as a shop window for London's tourist trade. In the organisers' words, 'Evocative landmarks familiar around the world will provide a tapestry of beauty and grandeur to showcase Olympic athletes in the heart of London, the world's most visited city." ${ }^{2}$

The tourist gaze may well focus on London's royal, political and ecclesiastical heritage, but the marathon will also draw our attention to London's sporting history. London's first Olympic marathon, run on Friday 24 July 1908 as part of the Fourth Olympiad, is one of the most famous events in Olympic history. The race from Windsor Castle to the Olympic Stadium in Shepherd's Bush, later known as the White City Stadium, was the origin of what is now the standard marathon distance - the 26 miles 385 yards that has no logic in either metric or imperial measuring systems. The race has also become famous because of its drama. The fancied British runners all did poorly, with only four of the II finishing; Canadian star Tom Longboat withdrew with stomach cramps and exhaustion. The first runner home, Dorando Pietri of Italy, collapsed on the track before crossing the line, and was helped up by British stewards, who then assisted him to the finish. His victory was short-lived, as American officials complained that Pietri could not have finished on his own, and that the victory should go to their runner, John Hayes, who crossed the line second. Their appeal was upheld, but the controversies around the help that was given to Pietri continued long after the race, and contributed to the rift in AngloAmerican sporting relations that came to be known as the Battle of Shepherd's Bush. ${ }^{3}$ The pathos of Pietri's run made him a hero. The press fêted him, Queen Alexandra awarded him a special trophy, and the young Irving Berlin composed a song about him.

Over the century since the race, Pietri has become more famous than Hayes, the real winner, and he ranks alongside Ben Johnson in 1988 as the most famous Olympic 'winner' who did not win. The Pietri story is central to all accounts of the I908 Olympics. This trend has been seen most graphically on the covers of many of the histories of 1908 that were published in the centenary year: for example, the dust jackets of Rebecca Jenkins' The First London Olympics I908, John Bryant's The Marathon Makers and Keith Baker's The I908 Olympics all carried the famous picture of Jack Andrew, the clerk of the course in his straw boater, ready to catch Pietri as he crossed the line. The story was also told from Beijing during the 2008 Olympics, with BBC commentator Brendan Foster talking about the 1908 race within minutes of the start of the men's marathon. Clearly, there is something resonant about London's first Olympic marathon.

Popular Olympic history usually concentrates on the drama of the event, and often overlooks the physical spaces in which those events took place. For the I908 marathon, while Windsor Castle and the stadium are always mentioned, it is easy to forget the less glamorous places in between: Slough, Uxbridge, Ruislip, Harrow and Harlesden are not the most obvious Olympic venues. Detailed local histories of Olympic events can tell us far more than this, and can take us beneath the simple city 
names - from Athens in 1896 to Beijing in 2008 - and into the suburbs and provinces where the games have happened. This kind of approach is necessary if we are to get a rounded picture of how large events such as the Olympics fit into the social, cultural and economic history of the host cities and countries. It is informed by John Bale's pioneering historical sports geography, particularly Landscapes of Modern Sport, which has provided sports historians with a framework for exploring the links that have existed between locations and the sport that has been played in them. Bale's application of the concept of 'topophilia' to sport has been particularly useful in helping us to understand the ways in which people, both as individuals and as members of communities, have invested stadiums and other sport sites with cultural values linked to memory and identity. ${ }^{4}$ Local studies of Olympic history are also informed by the literature on the geography of tourism and planning, such as John Gold and Margaret Gold's Olympic Cities, with its wealth of historical and contemporary discussions of how the Olympics fit into their city locations. ${ }^{5}$ The growth of sports heritage is also helping to set an agenda for the local study of sport, with its emphasis on the physical infrastructure of clubs, stadiums, pools, bowling greens and pubs that have underpinned real communities' sporting lives. ${ }^{6}$ It is in the context of this diverse work, and with the aim of adding depth to our knowledge of London's sporting history, that this paper explores the route of London's first Olympic marathon.

In most areas of sports history, it is impossible to identify the moment when a particular activity first happened. Despite the creation myths that some sports propagate about themselves, notably rugby union's William Webb Ellis moment and Abner Doubleday's inspiration for baseball, all sports have a history that is about evolution of form rather than sudden invention. ${ }^{7}$ The marathon, first held in 1896 , is one of the exceptions. Although it drew on a long tradition of distance running, both track-based and cross-country, the marathon's distance and its conceit were both created specifically for the first of the Olympics held under the auspices of the International Olympic Committee (IOC), at Athens in I896. De Coubertin's colleague Michel Bréal had the idea of staging a race that would help to link the new games to classical Greek history: as such, it was part of the invented tradition that characterised the modern Olympics. ${ }^{8}$ The ancient Olympic Games had not had any footraces longer than the dolchios, a stadium-based race of approximately three miles. John MacAloon claims that anything as long as the modern marathon would have been 'barbaric and abominable' to the ancients. 9 Bréal and de Coubertin, however, were working in a different time, a time in which endurance events in a range of sports were increasing in popularity. Matthew Webb had swum the English Channel in I875; motor racing promoters had set up a Paris to Vienna race in I9O2 and a 24-hour race at Brooklands in I907; and cyclists had the Tour de France from I903. Runners and pedestrians had been pushing the extremes of their sport throughout the nineteenth century, from Robert Barclay Allardice's I,000 miles in I,000 consecutive hours in 1809 , through to James Fowler-Dixon's 50 miles in 6 hours, 58 minutes and 16 seconds in 1885 , and the first London to Brighton race, held in I889. ${ }^{\circ}$ The marathon brought this endurance culture into the Olympics, with Bréal and de Coubertin inventing its legacy by linking the race — through its name and its geography - to ancient Greek military history. 
The idea came from the legend of the military messenger who, in $490 \mathrm{BC}$, ran to Athens from the battlefield at Marathon to carry the news that the Athenian army had beaten the Persian invaders, and who then died of exhaustion. ${ }^{\text {II }}$ The story is impossible to unpick at this distance, and it seems to be a conflated version of two classical accounts. Herodotus, writing in c. 449 BC, told the story of a messenger called Pheidippides running from Athens to Sparta to ask for help against the Persians. He is supposed to have covered the $230 \mathrm{~km}$ in a day, with some divine help along the route from Pan. ${ }^{\mathrm{I} 2}$ This version of the legend includes a phenomenal athletic effort by a messenger, but does not involve Marathon as a place or the messenger's death, and the distance involved had no bearing on the $40 \mathrm{~km}$ from Marathon to Athens that Bréal and de Coubertin favoured in I896. The version with a messenger running from Marathon to Athens appeared in Plutarch's On the Glory of Athens, written approximately 500 years after the events. Plutarch's version includes the Marathon to Athens run after the battle, and the messenger's death, but the messenger here was called Hersipus of Erchius or Eucles. ${ }^{\mathrm{I3}}$ These stories were well known in nineteenth-century Europe and America, and the conflated versions became popular with artists and writers. Jean-Paul Cortot's statue Le Soldat de Marathon annonçant la Victoire of I834, Luc-Olivier Merson's painting Le Soldat de Marathon of I869 and Robert Browning's poem 'Pheidippides' of I879 are three examples of how the story was represented. Browning's version had the messenger running from Athens to Sparta and back, and added in an anachronistic Victorian amateur ideology that sees Pan releasing Pheidippides from 'the racer's toil' with its 'vulgar reward'. Pheidippides then goes on to fight at Marathon before running back to Athens with the news of the victory, where 'he dies — the bliss!' ${ }^{\text {I4 }}$ It was this composite tradition in its Victorian iterations that informed the planners at Athens in I896. The marathon as a race was thus 'chartered in wishful legend, more than in history' from its birth. ${ }^{15}$

The marathon proved popular at the Athens Olympic Games in I896. Seventeen men attempted the $40-\mathrm{km}$ course from Marathon to the Panathinaikon Stadium in Athens. Ten of them finished. The race and its legends quickly caught the imagination of amateur athletics administrators and professional race promoters in Europe and the USA, and before the next Olympics in I900, long-distance races called marathons were being held in Paris, New York, Boston, Aszod, Copenhagen, and elsewhere. However, the Olympic marathon slumped at the poorly organised Paris games in 1900. There is some doubt over whether the marathon was formally staged as an Olympic event or not, as there was no mention of it in either the official programme of events published before the games, ${ }^{16}$ or in the official report published afterwards, and it was only in I9I2 that the IOC gave the race Olympic status. ${ }^{17}$ However, a 40,260-metre road race was staged, starting and finishing at Racing Club de France's track in the Bois de Boulogne, and consisting of a lap of the city's old walls. Sixteen runners started, including three Britons. The seven finishers were led home by Parisbased baker Michel Théato of Luxembourg, amid allegations of runners taking shortcuts and others being obstructed. The I904 version, at St Louis, revived the race somewhat, with its field of 32 runners, although it had its controversies. The dusty 39,996-metre course, and close proximity of cars to the runners, caused a number of athletes to have breathing problems. The first man home, Frederick Lorz, took a lift 
in a car for part of the way; and the real winner, Thomas Hicks, has become retrospectively problematic because of his well-publicised use of brandy and strychnine during the race. However, the race helped to publicise the marathon, and after I904, more clubs and promoters set up more city races. In I906, 52 runners started the tenth anniversary race at the Intercalated Olympic Games at Athens in 1906. ${ }^{\text {I8 }}$

By the time that the Olympics were first held in London, then, the marathon had become an established part of the games, supported by a network of annual city races. These events had helped to bring long-distance running into the fold of amateur athletics. However, in some respects, the marathon differed from other modern sports, in which standardisation and quantification were becoming central. The key issue was distance. Whereas swimmers and track runners knew the exact distance for which they were training, the marathon's length changed, depending on location. While $40 \mathrm{~km}$ (24.8 miles) was a notional norm, the Olympic routes had varied between 39,996 metres at St Louis in 1904 and 4I,860 at Athens in 1906, while the city marathons retained local peculiarities. Moreover, while track athletes were able to predict what the surfaces of their tracks would be like, marathon runners faced such mixtures as grass, metalled roads, dust tracks, and variable undulations. It was in this uncertain form as a popular event that defied standardisation that the marathon arrived in London.

The story of London's first Olympics has been told extensively in the books published in the centenary year. ${ }^{19}$ In addition, Mallon and Buchanan's book on the games is a meticulous account of all the events and the controversies that surrounded some of them, with statistical information and key primary documents, ${ }^{20}$ and the official report of the British Olympic Association (BOA) is comprehensive, albeit flawed with regard to some minor points. ${ }^{2 \mathrm{I}}$ Briefly, the Italian government withdrew its offer of Rome as the host city in 1906, owing to financial problems, and the newly formed BOA, supported by King Edward VII, offered London's services to the IOC. The IOC accepted. The BOA formed a subgroup, the British Olympic Council (BOC), to organise the games. It worked with the organisers of the Franco-British Exhibition, a trade fair that was planned for 1908. ${ }^{22}$ The exhibition was based on Wood Lane in Shepherd's Bush, west London, and the exhibition's organisers agreed to fund the construction of a new stadium for the Olympics in return for a percentage of gate receipts. Construction work for what was the first purpose-built Olympic Stadium, with its running track, cycling track, Ioo-metre swimming pool, infield for team games, and space for 80,000 spectators, began on 3I July 1907. Alongside the construction, the BOC worked with the IOC and governing bodies of various sports to establish a programme and agreed rules. ${ }^{23}$ However, despite these logistical and administrative developments, there was some ambivalence towards the project in Britain. For example, while some parts of the press — notably the Daily Mail, which had a vested interest in the success of the Franco-British Exhibition - were keen promoters of the games, other newspapers were less impressed. Even the sporting Athletic News carried the news of London being chosen to host the I908 Olympics in its minor 'Gleanings' column, alongside such small stories as Hertfordshire County Cricket Club's announcement of its annual profits. ${ }^{24}$ The ambivalence is even seen in the attitudes of some sports' governing bodies. The General Committee Minutes for 27 October 1906 of the Amateur Athletic Association (AAA) are telling on this point: 
'The proposal to hold the Olympic Games in I908, in London, about the middle of July was considered. It was decided to support the proposal on the understanding that the Sports take place after the A.A.A. Championships. ${ }^{25}$

As Mallon and Buchanan have shown, some of this ambivalence remained when the Olympics started. ${ }^{26}$ Some of the events, such as the jeu de paumme at Queen's Club and the motorboat racing on Southampton Water, were too small and too elitist to attract much attention. Others were seen as lesser events in their sporting calendars than existing competitions, such as the sailing at Ryde when compared to Cowes Week, and the lawn tennis at Wimbledon. The stadium events attracted tiny crowds in the first week, including 4,000 on Thursday I6 July, a turn-out blamed on a combination of poor weather, expensive ticketing, and the fact that many people did not regard the sports as anything special. However, as the stadium events went on, they got increasing amounts of press coverage, particularly as the Anglo-American animosity around the officiating developed through the tug of war on I7 and I8 July and the abandoned 400 -metres final on $23 \mathrm{July} ;{ }^{27}$ and the marathon, coming on the last day of competition, built on this accumulating interest. The stadium was packed to its capacity of 80,000 to watch the race's climax, and tens of thousands more spectators watched along the route. From the first stages of planning, through the trials and on to the race itself, the marathon caught people's imaginations, and became a defining moment in the I908 Olympics. In this context, it is worth going back beyond the start of the Olympics to see the route's history.

Since the late nineteenth century, long-distance running and cross-country running in the UK had been influenced by the amateur ideals that were enshrined in the AAA's version of sport. Professional pedestrian culture, including its betting-based extreme time and distance challenges, had been falling out of fashion, and the amateur model had become more attractive. The Olympics, however, had made a relatively minor impact in the UK, and the marathon had not inspired club events in British cities, as had happened in Boston, Paris, and elsewhere. Some British professionals had competed in some of the new city marathons, led by Len Hurst, who won the I896 Paris-Conflans $40-\mathrm{km}$ race. However, the distance remained a minority interest in amateur British circles. Only five Britons attempted the Olympic marathon before it went to London in 1908. No Britons entered the original race in Athens. Three William Saward of Essex Beagles, Ernest Pool of London AC, and Derek Randall of Finchley Harriers - attempted it in Paris in I900, although none of them finished. There were no Britons in the marathon at St Louis, and only two at Athens in I906: Joseph Cormack, who became the first Briton to complete an Olympic marathon,

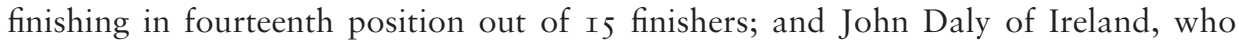
was among the non-finishers. This was a not a great tradition on which to build a domestic Olympic marathon, certainly when compared to the speed with which North American athletics had taken to the amateur marathon model, but it did show a small degree of interest.

This lack of a tradition showed when it came to planning and staging the race in I908. The BOC delegated the planning of each sport to the relevant governing body. According to one commentator, the BOC was 'somewhat chary of the formidable task of attempting to hold a big road event near London', but it knew that the marathon was already being seen as a flagship event for the Olympics ${ }^{28}$ so it devolved 
the race to the AAA. However, the AAA was inexperienced with races of this distance. By I908, its own championships, which had been held annually since I 880 and which attracted athletes from the UK and overseas, included races over one, four and Io miles, but nothing longer, and long-distance races held under its auspices were rare. ${ }^{29}$ The AAA endorsed some occasional long-distance events, such as FowlerDixon's 50-mile run in I885, and Cartwright's Ioo-mile event in I887, but by the I90os these had diminished, and Herne Hill Harrier Fred Appleby's world record of I hour, 20 minutes and 4 seconds for I 5 miles at Stamford Bridge in July I902 stands out for its length in the Edwardian period. The greatest distance runner of this generation, Alf Shrubb, did not compete in marathons during his amateur years before 1905 , despite breaking records at a range of distances in both track and crosscountry events. Indeed, in his training manual Running and Cross-Country Running of I908, he covered any event longer than four miles in a single chapter called 'LongJourney Races, such as the Marathon and Others'. He observed that 'our amateurs don't lay themselves out for any races over ten miles as a rule', but encouraged them to try it. ${ }^{30}$ So, whereas in 1908 the AAA had no difficulty in organising Olympic versions of its regular track and field events, it was inexperienced and uncomfortable in planning a $40-\mathrm{km}$ race. At its meeting on 5 October 1907 , the AAA deferred the 'choice of the course for the marathon Race' to its Track Committee, which it had formed to help organise the Olympic athletics. ${ }^{3 \mathrm{I}}$

Late in 1907, the AAA's problem was solved by Jack Andrew, the honorary secretary of the London-based Polytechnic Harriers, who offered his club's services to organise a British trial and the Olympic race itself. The Polytechnic Harriers was based in the Young Men's Christian Institute (YMCI) in Regent Street, a pioneering establishment that taught vocational skills to professional levels. Under the motto of 'The Lord is Our Strength', the YMCI had a strong tradition of sport based in muscular Christianity, largely through the influence of its chief benefactor, the philanthropist Quintin Hogg. The YMCI moved into the premises of the Royal Polytechnic Institution on Regent Street in I882, when it started to be known as the Polytechnic, and its athletics club, the Polytechnic Harriers, was established in I883. It was based at the Polytechnic's playing fields at Merton in Surrey until I906, when the new Quintin Hogg Recreation Ground, funded by subscription after Hogg's death in I903, opened at Chiswick in west London. By I908, the Polytechnic Harriers was one of London's leading athletics clubs. ${ }^{32}$ It was experienced in organising long-distance races over public highways, having staged two London to Brighton races, and in its honorary secretary, Andrew, 'the indefatigable Jack', 33 it had a dynamic and well-connected organiser who undertook the 'arduous undertaking' of organising the marathon. ${ }^{34}$

It was from this basis, and with 'the object of stimulating interest in long-distance running' ${ }^{35}$ among British amateurs and education establishments, that Andrew offered the AAA his club's services. The AAA accepted the offer early in I908, noting at its General Committee meeting on 8 February that 'With regard to the Marathon Race, it was agreed that the Polytechnic H's. 20 Miles race should be regarded as the Trial Race'. ${ }^{36}$ The original agreement was for the Polytechnic Harriers to plan a route and organise a race 'at or near the distance' in April I908, which would then serve as the main trial from which the British Olympic team could be selected. ${ }^{37}$ However, 
this arrangement quickly evolved so that the trial route would also serve as the basis of the Olympic route, and the Polytechnic Harriers, led by Andrew and his Management Committee, effectively took on the organisation of both races. The distance for the Olympic race was not rigid. The IOC's regulations for the games, established at its conference in The Hague 1907, stated that the race should be about $40 \mathrm{~km}$ (24.2 miles) long; but the experience of the first four Olympic marathons suggested that there was some flexibility with this. As we have seen, the Olympic distance had varied between 39,996 metres at St Louis in I904 to 4I,860 metres at Athens in $1906 .{ }^{38}$ As the stadium would not be ready in April to host any of the trials, the Polytechnic Harriers chose the trotting track at the Metropolitan Railway's leisure grounds of Wembley Park, roughly four miles from Wood Lane, for the finishing line for the trial, with the route then being extended to the stadium for the Olympic race. Working from there, the route had to avoid main roads when possible, so as to prevent disruptions to traffic and trade. This constraint, which underlines the relative insignificance of the race when compared to our current assumptions about how an Olympic marathon can advertise a city, made a central London route impossible. ${ }^{39}$

The planners chose Windsor Castle, 2I miles from Wembley Park and 26 miles (over a mile longer than the guide distance of $40 \mathrm{~km}$ ) from the Olympic Stadium, as the starting point. There was no formal requirement for the event to start in the stadium, although it was taken as read that it would finish there: the crowd scenes from Athens in particular, and the opportunities for a full house to see the finish, were beyond question. The Paris and St Louis versions had been loops, starting and finishing on the track, but the Athens versions had started away from the stadium, and had worked as point-to-points. Andrew seems to have been taken with the Athenian model, which itself went back to Bréal's original idea of a 'sporting event relevant to Greek history', ${ }^{\circ}$ and he developed a route that 'tended to arouse a decided historical sentiment'. ${ }^{\text {I }}$ Rather than the battlefield conceit that was used in Athens, the Polytechnic Harriers' history was more royal, being based on Windsor Castle, which had a history stretching back over 800 years, and was an icon of British royal tradition dating back to William the Conqueror. By I908, when the marathon was being planned, Windsor Castle was a favourite home of many in the royal family, and its familiar neo-Gothic towers dominated the skyline for miles around. The royal connection was cemented in March, when the Polytechnic Harriers announced that King Edward VII had 'graciously given his consent' to the trial starting in Windsor Great Park. ${ }^{42}$ From here, the route's 'historical sentiment' was extended by passing close to Eton College and Harrow, two of England's oldest and most prestigious public schools. ${ }^{43}$ History and royal patronage were thus central to the route from the start. This legacy was stressed on the front of the race's official programme, with Windsor Castle rather than the stadium or anything athletic being the centrepiece (Figure I).

Working between Windsor and Wembley, and then onwards to the Olympic Stadium, Andrew and his colleagues mapped out the route. It was in place by the end of February 1908, when the Management Committee asked the Metropolitan Police for permission to use public highways. In his letter to the chief commissioner of 29 February, Mitchell of the Polytechnic Harriers described the route for the 'great Marathon Race' in the Olympics as being from Windsor to Shepherd's Bush via Slough, Ruislip, Pinner, Harrow, Wembley, Willesden, and Wormwood Scrubs, and 


\section{OLYMPIC GAMES, 1908.}

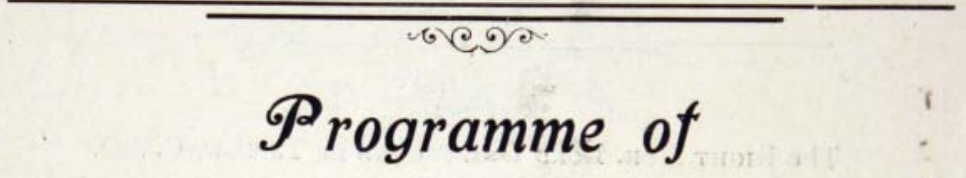

Marathon Race

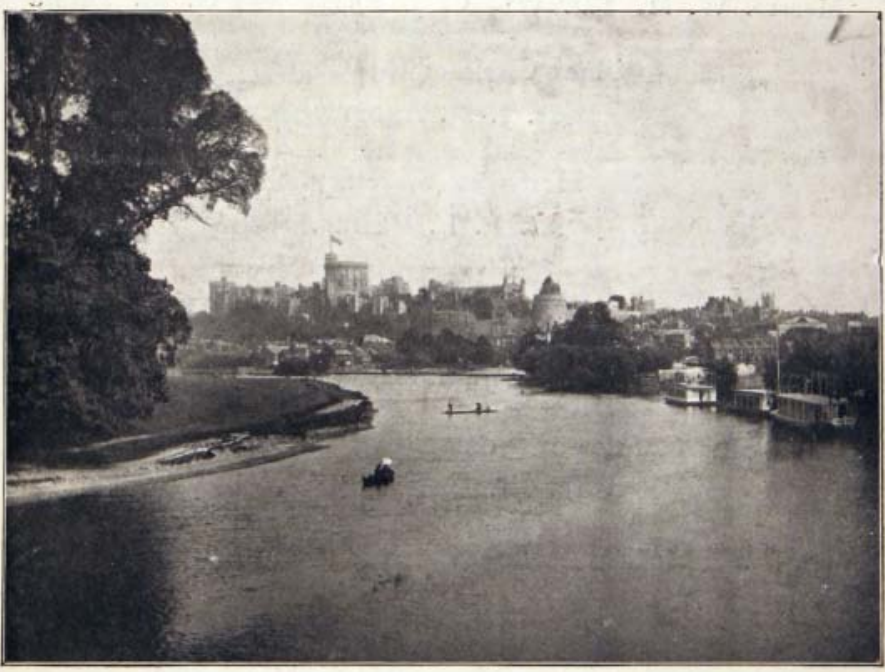

WINDSOR CASTLE.

\section{Windsor Castle}

TO THE

\section{Great Stadium,}

Shepherd's Bush, W.

\section{Friday, July 24t6, 1908.}

FIGURE 1 The front cover of the Olympic Marathon programme, 24 July 1908. Reproduced by permission of Special Collections, Academic Services, University of Birmingham. 
explained how the Polytechnic Harrier's trial race on 25 April would use the same route, but stop at Wembley Park 'so that traffic would not be impeded in the busy part of the outskirts', a clear statement of the planners' desire to cause as little disruption as possible. Mitchell also stressed the sporting significance of the trial on the Olympic route, as it would 'give British competitors every opportunity of achieving success' in the Olympics. ${ }^{44}$ The routes for both races were in the public domain by early April, when The Polytechnic Magazine reported on the progress of the event: 'The course for this year's race will be from Windsor Castle to the Stadium, a lap of the running track being completed at the finish.' The same report referred to the idea of the race starting on the castle's terrace, and that the 'distance will be about 26 miles to the edge of the Stadium track'. ${ }^{45}$ The map that the Polytechnic Harriers produced at this time showed the full route, ending at the stadium, although the final stages were changed shortly before race day (Figure 2 )..$^{46}$

What, then, as of April I908, was the route? As well as the official map of the route, two additional contemporary sources give us an excellent flavour of it. First is the official written version, which appeared in the trial programme, the Olympic programme, and Cook's post-Olympic official report. This gave detailed directions, including the naming of such landmarks as Roxborough Hotel in Harrow, the Great Western Railway at Slough, and Pinner Gas Works, as well as road names. ${ }^{47}$ The second source is the feature in the Illustrated London News on the marathon in its I8 July I908 edition, which juxtaposed a map of the route with photographs and drawings of the view at each mile marker. ${ }^{48}$ Taken together, these sources show us that the route had nothing to do with central London: it went through countryside, market towns, and suburbs, but got no closer to the centre of London than the stadium, four miles west of Hyde Park Corner. From Windsor, the route crossed the River Thames, then pressed north through Eton, a small town dominated by its medieval school, and on to the market town of Slough. Here, it turned east towards London, before turning north-east to Uxbridge. This stretch was mainly rural, passing through parkland and skirting the edge of some villages, such as Iver Heath. It crossed the River Colne, and then went through Uxbridge, another market town, with a slight south-east turn, before heading north/north-east again across Uxbridge Common and on to Ruislip, Eastcote, and Pinner. At Pinner, the route turned south through Harrow and Sudbury and on to the finishing point at Wembley Park. This route certainly avoided any busy areas: indeed, the end point at Wembley Park was close to the north-eastern terminus of London's tram services, the section of tramlines to Wembley having opened only I 5 days before the trial.

From the point at which the trialists turned off into Wembley Park, the Olympians would continue on a wholly suburban route. They would follow the tramlines from Wembley to the Victorian suburb of Harlesden, where they would cross the railway and head south along Old Oak Lane and onto the common ground of Wormwood Scrubs, an area of grassland that had been one of London's main duelling grounds and was now, under the terms of the Wormwood Scrubs Act of I879, an area used for cavalry training and shooting clubs. From here, the route passed between Wormwood Scrubs prison, completed in I89I, and Hammersmith Poor Law Guardians' new infirmary, which had started off as a smallpox isolation hospital in I902 but was, by 1908 , operating as a hospital for workhouse inmates too sick to work. The route then went along Ducane Road, named after the prison's designer, Sir Edmund Du 


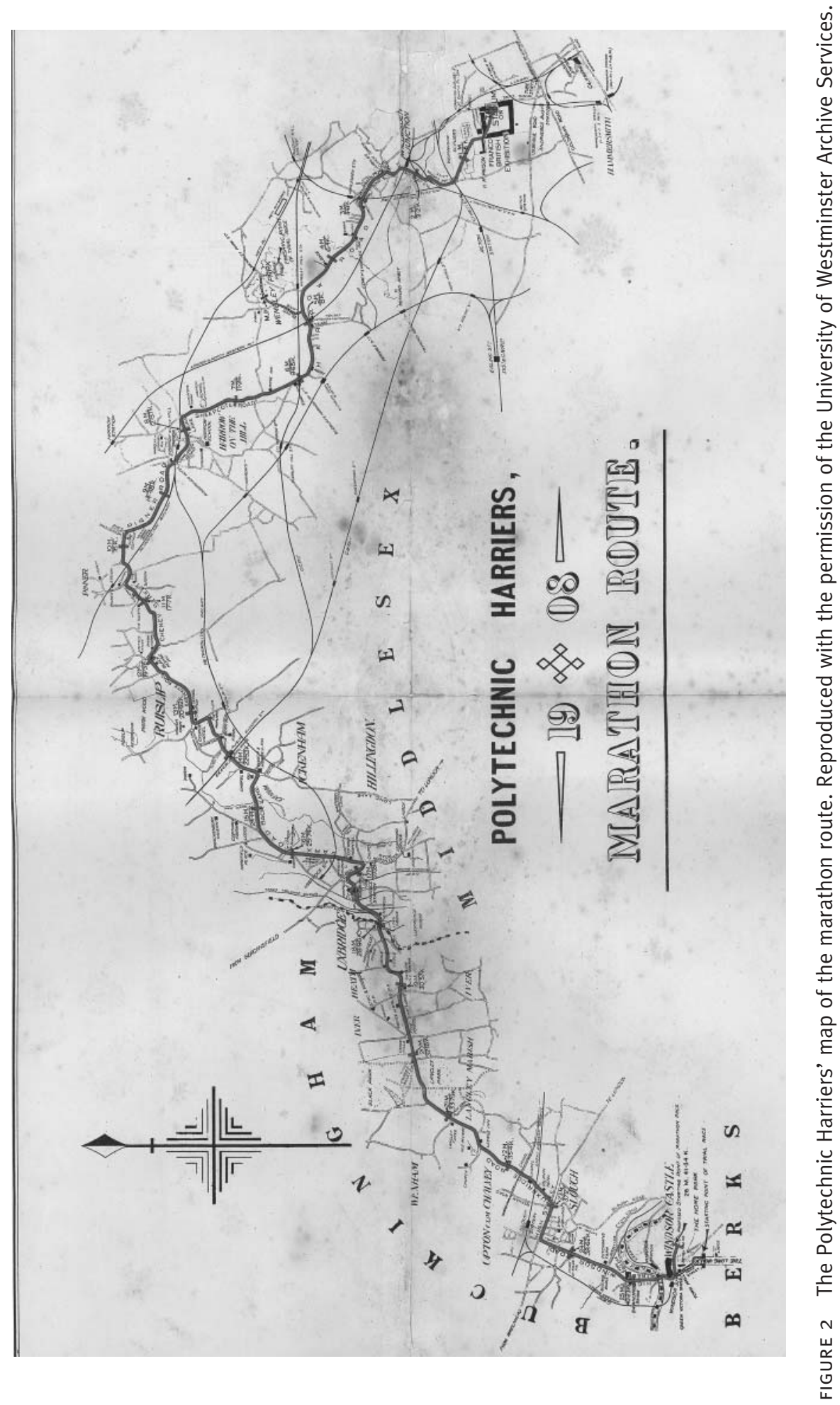


Cane, and then into the stadium. Including a stretch on the track, designed to achieve a finish that the crowd could enjoy, this route would be 26 miles, 385 yards, or 42, I95 metres. It was thus the longest Olympic marathon route to date, 335 metres longer than the Athens course from I906, and 2,I95 metres longer than the notional $40 \mathrm{~km}$ originally announced.

Andrew was tireless in his organisation of the race: as one commentator noted:

He commandeered the prizes from various good friends of the club; had a great scale map made at goodness knows what cost; ... interviewed endless surveyors, mayors, councillors, police superintendents, water cart directors ...; fixed a sign-post here and another on a garden wall there, and generally played the deuce all down the road. ${ }^{49}$

With his colleagues, particularly Mitchell, Andrew worked hard to get permission from the various authorities that had an interest in the route: the king for Windsor Castle, the local councils whose roads the races were due to use, the three police forces involved for road closures, public order, and safety reasons, and the various volunteers involved as marshals, as support cyclists, and in many other roles. ${ }^{50}$ Other support for the event came from commercial interests. The organisers worked with hoteliers and caterers along the route for a range of facilities for both the trial and the Olympic race. The Poplars, a tea room at the southern edge of Ruislip, The George in Ruislip and Ye Cocoa Tree Hotel in Pinner all offered special residential packages of between 35 and 40 shillings per week to competitors in the trial. These deals allowed trialists coming from a distance to train on the route ahead of the race day. ${ }^{5 \mathrm{I}}$ In addition, The Poplars and The George, along with the Crooked Billet at Iver Heath, the King's Arms Hotel in Uxbridge, The Roxborough Hotel in Harrow, and the Pavilion at Wembley Park, all offered washing and refreshment facilities for the runners in both races. ${ }^{2}$ The Great Western Railway put on a special train from London's Paddington Station to Windsor, and allowed the runners to change in the waiting room at Windsor Station. The transport links also ensured that thousands of people, both suburban and urban dwellers, could get to see the race for free, with special train services carrying passengers from Paddington to key viewing locations. Finally, the Polytechnic Harriers secured commercial support for both races from Oxo, the manufacturers of a beef extract product. Having Oxo products associated with an endurance event provided some well-placed advertising. The runners were all provided with Oxo flasks, containing hot and cold Oxo, rice pudding, and bananas. ${ }^{53}$ These races were modern sporting events, and the evidence of the race's organisation shows how, even at this early stage, the Olympics inter-related with their social, political, and commercial settings. They were also spectator events, although the terrible weather for the trial limited the crowds. While the inherent lack of firm evidence for spectators outside the stadium for the Olympic race makes any comments about numbers or social profiles of the crowds rather impressionistic, photographs show men and women, and children of both sexes, along the route, with heavy concentrations in Windsor, Slough, Harrow, and on Wormwood Scrubs; the crowds on the pavement at Harlesden were Io deep in places. Spectators' clothing suggests that the race appealed across class boundaries, and that suburban and central Londoners of all types were drawn to this extraordinary event.

This course, which has become so central to Olympic history, was used just twice for Olympic purposes. On 25 April 1908, Alexander Duncan of Salford Harriers 
won the Polytechnic's trial over the short version from Windsor Great Park to Wembley. The trial went well, attracting 68 starters, and all aspects of the course's management - from the Polytechnic Cycling Club's support riders to the policing of the course - proved to be a good experience for the real event. ${ }^{54}$ The Olympic race, two months later, had a slightly different starting point, the runners being moved to the castle's lawn so that the royal children could watch. Apart from that, it followed the same route to Wembley, plus the extension on to the Olympic Stadium. The race, and the controversies to which its end gave rise, have been well documented elsewhere. ${ }^{55}$ The race's popularity was shown by the rematches that quickly followed, as some of the leading runners from 1908 turned professional after the Olympics and ran against each other and new challengers over the 1908 distance. Pietri, Hayes, the Canadian Tom Longboat and others in various combinations raced each other over 26 miles 385 yards in New York, Buffalo, St Louis, Chicago, and San Francisco. The distance was used in British races, both amateur and professional, the latter including Pietri's return to London, when he raced Charles Gardiner over the distance on a track inside the Royal Albert Hall in December 1909. ${ }^{56}$ The race's popularity in London, as witnessed not just by the race's fame but also by its success as a suburban spectator event, led to a wave of imitators. Some of these exercised the Home Office, which had to work out the legal status of foot-races over public highways. ${ }^{57}$ The next two Olympic marathons, however, were over different distances. At Stockholm in I9I2, the race was shortened to 40,200 metres. At Antwerp in I920, the runners had to deal with the longest marathon in Olympic history, 42,750 metres (26 miles 992 yards). A year after Antwerp, the International Amateur Athletics Federation settled on a permanent distance for Olympic marathons, taking the London I908 course as the standard length..$^{8}$ The legacy of the route from Windsor to White City has thus been celebrated in Olympic cities as diverse as Paris, Mexico City, Moscow, Atlanta, Seoul, and Beijing. The distance has also become standard in non-Olympic city marathons from Sydney to Reykjavik, and Johannesburg to New York City.

As well as the distance becoming standardised, the I908 course and the stadium in which it finished had their own afterlives. The stadium was originally scheduled to be demolished after the Franco-British Exhibition. However, it survived - with additions and adaptations to the track, the infield, and the spectator areas - until I985, being known as the White City Stadium long after the exhibition buildings from which it took its name had been demolished. White City hosted athletics, including the AAA's annual championships from 1932 until I970, rugby league, football, greyhound racing, and speedway. It was finally flattened in 1985 , and the site was redeveloped as the BBC's Media Village. However, unlike the iron and concrete of the stadium, the marathon route through suburbs, market towns and country roads was inherently ephemeral, although it still survived beyond I908. The Polytechnic Harriers maintained part of the route as the course for its marathon, which Andrew instituted in 1909 in cooperation with Sporting Life as a way of improving British amateur distance running after the poor performances of I908. Between I909 and I932, with breaks in the war years, the Polytechnic marathon used part of the 1908 route, but ended at Stamford Bridge instead of White City. From I933 to I937, the original 1908 route was revived, with the runners finishing at White City, after which the finish was transferred to the Polytechnic's new stadium at Chiswick. From I939 until I972 (with some breaks), the Polytechnic course continued to cover the I908 
route as far as Wembley, before heading south through Ealing and Brentford to Chiswick. The race moved to the Windsor area in 1973, with a brief revival of the Windsor to Chiswick route in the mid-I990s, but then folded as more clubs and organisations were putting on marathons and more accessible races, such as halfmarathons and Io-km runs. ${ }^{59}$ However, other marathon races in the capital eschewed the 1908 route entirely. When the Olympics returned to London in I948, they were based at the Empire Stadium, Wembley, and the marathon route did not overlap with the I908 course; instead, it was an out-and-back route from Wembley into Hertfordshire, with the turning point at Radlett. The London marathon, set up by Christopher Brasher and John Disley in I98I as a response to the New York City marathon, has redefined distance running in the capital. This race, which attracted 7,500 runners in its first year, has grown in popularity, with over 36,000 starters in 2008 . This new race had nothing to do with the 1908 route. Instead, it exploited the centre of London and many of its famous sights. From the start at Greenwich Park to the end on The Mall, this race takes in the Cutty Sark, Tower Bridge, and the Tower of London, and stays close to the River Thames for much of the way; it is a marathon for the capital city in a way that the 1908 route and its Polytechnic survival had never been. ${ }^{60}$ It is this route, rather than anything from London's previous Olympic marathons of 1908 or I948, that has formed the template for the $20 \mathrm{I} 2$ Olympic marathon.

The I908 distance has thus entered the mainstream. A century on, however, the 1908 route is not particularly accessible or welcoming as a sporting site. Some devoted runners take on the challenge of keeping the route alive by running it, most recently marathon historian John Bryant and journalist Steve Seaton in costume as Pietri and Hayes, respectively, on the centenary of the original Olympic race, ${ }^{6 \mathrm{I}}$ but it is not a promising route. It is not easy for enthusiasts to get the sense of Bale's topophilia that stadiums and other more tangible sport sites can inspire. Twickenham, Lord's, Wimbledon and Stamford Bridge have their tours and museum experiences, but the same cannot happen on a 26-mile stretch of country roads, dual carriageways, pedestrianised town centres, and suburban shopping streets, with the stadium replaced by offices. However, rather than look for topophiliac relationships with the route, we can perhaps develop a sense of associative significance with it, an appreciation of how an extraordinary event happened in a rather ordinary landscape. Some parts of the course are still recognisable from the photographs of the race, most notably at the start outside Windsor Castle, outside Eton College, in central Ruislip, outside Railway Cottages in Harlesden, and on Wormwood Scrubs. ${ }^{62}$ These can give us a sense of immediacy. However, in other places the route has been destroyed, diverted, or diluted. The $\mathrm{M}_{4}$ now cuts through the route between Eton and Slough, as does the M25 west of Uxbridge and the North Circular Road east of Wembley. Town centre developments in Uxbridge and Harrow have changed the path, while the last halfmile is wholly irrecoverable. The Central Line running north-west between White City and East Acton, and the A40, have cut off the runners' access route from DuCane Road, and there is nothing left of the stadium. Marathon routes, unlike the buildings that people construct to play their sports in, are ephemeral, and are not meant to leave traces, so this loss is understandable and necessary; town development cannot fossilise around a race's route, however famous the race.

Instead of fossilisation, there is some commemoration and survival. The BBC's Media Village has a large plaque in its courtyard area giving the medal table for the 
I908 Olympics, and naming the winners, and a line of text on the pavement marks the finishing line's position. Outside the BBC, the road that divides it from the White City estate is called Dorando Close, named after Dorando Pietri. These three markers are recent, put up to commemorate the race. Further back, just over a mile from the start, we can go beyond commemoration and into survival. The race's only definite physical trace still in place is an original mile marker fixed to a wall at Barnes Pool Bridge in Eton. It carries the Polytechnic Harriers' badge, points the way north, and gives the distance still left to run in imperial and metric measurements. This fragment, like any historical artefact that we find in its original context, can give us an immediate way into the race. It is representative of the work that went into the marathon, how the race was organised and managed, and how the runners engaged with the route. The mile marker, taken with other contemporary evidence of the race, can help us get a sense of how the Olympics have never been restricted to stadiums, but have taken place in ordinary communities. London's history, and the history of the Olympics, can only benefit from localised research that helps to bring these communities back into the story.

\section{Notes}

I London2or2, 'Sports \& Venues', http://www. london2OI2.com/sports-and-venues.php (accessed Sep 2008).

2 London Development Agency, 'London 20I2 Olympic marathon to feature much loved landmarks to inspire athletes from Tower Bridge to Buckingham Palace, Houses of Parliament and Westminster Abbey',http://www.lda.gov.uk/server/show/ConWebDoc.989 (accessed Sep 2008).

3 The best concise narrative of the race is D. Martin and R. Gynn, The Olympic Marathon: The History and Drama of Sport's Most Challenging Event (Champaign, IL, 2000), 63-80. See also B. Mallon and I. Buchanan, The I908 Olympic Games: Results for All Competitors in All Events, with Commentary (Jefferson, NC), 63-7, 3I3-406; G. Kent, Olympic Follies: The Madness and Mayhem of the I908 London Games: A Cautionary Tale (London, 2008), I54-70; K. Baker, The I908 Olympics: The First London Games (Cheltenham, 2008), II 5-26; R. Jenkins, The First London Olympics 1908 (2008), I88-26I; J. Bryant, The Marathon Makers (2008); and B. Wilcock, The 1908 Olympic Games, the Great Stadium and the Marathon: A Pictorial record (Brentwood, 2008).

4 J. Bale, Landscapes of Modern Sport (Leicester, I996).

5 J. Gold and M. Gold (eds), Olympic Cities: City Agendas, Planning, and the World's Games, I8962012 (2007).

6 See, for example, S. Inglis, Played in Manchester: Charting the Heritage of a City at Play (2004); S. Beauchampé and S. Inglis, Played in Birmingham: Charting the Heritage of a City at Play (2006); R.
Physick, Played in Liverpool: Charting the Heritage of a City at Play (2007); J. Smith, Liquid Assets: the Lidos and Open Air Swimming Pools of Britain (2005); and H. Hornby, Uppies and Downies: the Extraordinary Football Games of Britain (2008).

7 M. Polley, Sports History: A Practical Guide (Basingstoke, 2007), 25-7.

8 Martin and Gynn, Olympic Marathon, 5-6. For de Coubertin, and for the Athens Olympics as a whole, see J. MacAloon, This Great Symbol: Pierre de Coubertin and the Origins of the Modern Olympic Games (Chicago, I984); D. Young, The Modern Olympics: a Struggle for Revival (Baltimore, 1996); and M. L. Smith, Olympics in Athens 1896: The Invention of the Modern Olympic Games (2004)

9 MacAloon, This Great Symbol, 225.

Io P. Radford, The Celebrated Captain Barclay: Sport, Money and Fame in Regency Britain (200I); For the AAA's development before I908, see P. Lovesey, The Official Centenary History of the Amateur Athletic Association (Enfield, I979), I3-64.

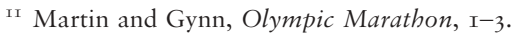

${ }^{\mathrm{I} 2}$ Herodotus, The Histories (Harmondsworth, I972), 425 .

${ }^{\text {I3 }}$ F. J. Frost, 'The Dubious Origins of the Marathon', American Journal of Ancient History, 4 (1979), I59-63; MacAloon, This Great Symbol, 225-6.

${ }^{\text {I4 }}$ R. Browning, 'Pheidippides', in J. Pettigrew (ed.), Robert Browning: The Poems, vol. 2 (New Haven, CT, I98I), 585-8.

${ }^{15}$ MacAloon, This Great Symbol, 225.

${ }^{16}$ Facsimile in Martin and Gynn, Olympic Marathon, 26.

${ }^{17}$ Martin and Gynn, Olympic Marathon, 36. 
${ }^{18}$ For narratives and statistics for all of these races, see Martin and Gynn, Olympic Marathon, 9-62.

I9 Bryant, Marathon Makers; Jenkins, First London Olympics.

${ }^{20}$ Mallon and Buchanan, I908 Olympic Games.

${ }^{2 I}$ T. Cook (ed.), The Fourth Olympiad: Being the Official Report: The Olympic Games of I908 Celebrated in London Under the Patronage of His Most Gracious majesty King Edward VII and by the Sanction of the International Olympic Committee (I908).

${ }^{22}$ For the agreement between the BOC and the Franco-British Exhibition, see BOC Minutes, 20 Dec I906, BOA Library, London.

${ }^{23}$ For the regulations, see Cook, Fourth Olympiad, 29-3I, and for the rules governing all sports, see Cook, Fourth Olympiad, 4I2-625. See also BOC Council Minutes, BOA Library.

${ }^{24}$ Athletic News (3 Dec 1906).

25 AAA General Committee Minutes, 27 Oct 1906. University of Birmingham Special Collections, AAA papers, $\mathrm{AAA} / \mathrm{I} / 2 / 2 / 4$.

${ }^{26}$ For attendance figures, see Mallon and Buchanan, I908 Olympic Games, 22-3.

27 Mallon and Buchanan, I908 Olympic Games, 52-7, 268-7I; Jenkins, First London Olympics, I32-87.

${ }^{28}$ C. J. P. , 'The Polytechnic Marathon Trial Race, Windsor Park to Wembley Park: A Grand Performance', The Polytechnic Magazine, XLVIII:3 (I908), 40.

29 Lovesey, Centenary History, I8I-3.

$3^{\circ}$ A. Shrubb, Running and Cross-Country Running (I908), 64 .

${ }^{31}$ AAA General Committee Minutes, 5 Oct 1907. University of Birmingham Special Collections, AAA papers, $\mathrm{AAA} / \mathrm{I} / 2 / 2 / 4$.

32 'Polytechnic Harriers', http://www.aim25.ac.uk/ (accessed Sep 2008).

33 C. J. P. , 'The Polytechnic Marathon Trial Race', 40.

${ }^{34}$ M. A. J. , 'The Great Marathon Race, I908', The Polytechnic Magazine, XLVIII:2 (I908), 20.

35 Polytechnic Harriers Marathon Trial Race, 25 Apr I908, Official Programme, 8. Copy in University of Westminster Archives, PHA 5/2, File I.

${ }^{6} 6$ AAA General Committee Minutes, 8 Feb I908. University of Birmingham Special Collections, AAA papers, $\mathrm{AAA} / \mathrm{I} / 2 / 2 / 4$.
37 C. J. P. , 'The Polytechnic Marathon Trial Race', 40.

$3^{8}$ See Martin and Gynn, Olympic Marathon, 460, for a table of all Olympic marathon distances.

39 Marathon Trial Race, Official Programme, 9.

$4^{\circ}$ Martin and Gynn, Olympic Marathon, 6

${ }^{4 I}$ Marathon Trial Race, Official Programme, 9.

42 'In and About the Poly', The Polytechnic Magazine, XLVIII:I (I908), I.

43 Marathon Trial Race, Official Programme, 9.

${ }^{44}$ Robert Mitchell to Chief Commissioner of the Metropolitan Police, 29 Feb I908. National Archives (NA), MEPO $2 / 1156$.

45 M. A. J. , 'Great Marathon Race', I9.

${ }^{6}$ Wilcock, I908 Olympic Games, 3 I-2.

47 Programme of Marathon Race from Windsor Castle to the Great Stadium, Shepherd's Bush, W. , Friday, 24 Jul I908, I4-I5. Copy in Walter Barnard's scrapbook, University of Birmingham Special Collections, $\mathrm{AAA} / 4 / 3$.

${ }^{8}$ Illustrated London News (I8 Jul I908), 90-I.

49 C. J. P. , 'The Polytechnic Marathon Trial Race', 40.

${ }^{\circ}$ M. A. J. , 'Great Marathon Race', I9-20.

${ }^{51}$ Marathon Trial Race, Official Programme, I6.

${ }^{52}$ Marathon Trial Race, Official Programme, II; Programme of Marathon Race, 7.

53 Programme of Marathon Race, 7.

54 C. J. P. , 'The Polytechnic Marathon Trail Race', 40.

55 See Note 3.

${ }^{56}$ Bryant, Marathon Makers, 3II-I4.

57 NA, HO 45/11052 and $\mathrm{LO}_{3} / 279$.

$5^{8}$ Martin and Gynn, Olympic Marathon, 84, 99, II3.

59 Ian Ridpath, 'The Polytechnic Marathon 1909-I996', http://www.ianridpath.com/polymarathon/history. htm (accessed Jun 2008).

${ }^{60} \mathrm{~J}$. Bryant, The London Marathon: The History of the Greatest Race on Earth (2006).

6I 'London Salutes roo Years of the Marathon Distance', http://www.london-marathon.co.uk/site/?pageID= $5 \& n={ }_{147}$ (accessed Sep 2008).

${ }^{62}$ Wilcock, I908 Olympic Games, 34-44; includes descriptions of the exact locations of various photographs from the race.

\section{Notes on Contributor}

Martin Polley is Senior Lecturer in Sport at the University of Southampton. He is the author of Moving the Goalposts: a History of Sport and Society Since I945 (I998) and Sports History: a Practical Guide (2007), and is currently writing The British Olympics I6I2-20I2 for English Heritage's 'Played in Britain' series. 